\title{
Applying Metacognitive Strategies to Teaching ENGINEERING INNOVATION, DESIGN, AND LEADERSHIP
}

\author{
Marnie Vegessi Jamieson and John M. Shaw \\ Department of Chemical and Materials Engineering, Faculty of Engineering, University of Alberta \\ mvjamies@ualberta.ca and jmshaw@ualberta.ca
}

\begin{abstract}
To encourage innovation and positive team behavior, a bonus innovation assignment is included at the start of the introductory design course. Students are encouraged to choose from a reading list and insert themselves in the material to explore how leadership, creativity, and innovation might impact their design team experience. Students are then introduced to CATME and asked to evaluate themselves and their team members on a monthly basis as they work on lab assignments and project work in a cooperative learning environment. Capstone and introductory design students assess their individual skills relative to the Canadian Engineering Accreditation Board (CEAB) graduate attributes (GA) pre and post course, including teamwork skills. In addition, capstone student design teams use reflection to self-assess team function based on their perceived attainment of team level, and confidence in their ability to perform categorized skills related to team performance, technical performance, planning and logistics performance. The goals of these changes are to provide a collaborative framework for students to construct activities to learn and develop innovation, team, and leadership skills. This report focuses on the structure of the cooperative learning framework and the development of five cooperative learning criteria: positive interdependence, individual accountability, face-to-face interaction, appropriate use of interpersonal skills, and regular assessment of group functioning. Assignment effectiveness is demonstrated.
\end{abstract}

Keywords: Engineering Innovation, Leadership, Teamwork, Cooperative Learning, Accreditation, Student, Self, Outcomes, Course, Assessment, Graduate Attributes

\section{INTRODUCTION}

Innovation, Design, and Leadership are sought after traits in engineering graduates and seasoned practitioners alike. The Canadian Engineering Accreditation Board (CEAB) includes design, professionalism, and the ability to work as a member and leader of a team as key attributes of engineering graduates. Undergraduate program requirements may not explicitly include innovation and leadership although they may be addressed through extra curricular activities or in team based courses including design courses. When included in the curriculum of a team-based capstone design course, an already heavy workload may be increased and team performance impaired by team dysfunction. Previously developed student leadership and self-knowledge can be empowering. Metacognitive and reflective activities can increase learning and team function.

\subsection{Motivation}

During a review of CEAB GA criteria and chemical engineering design course objectives [9], consideration was given to the construction and assessment of learning activities to support teamwork, innovation, and leadership skill development as part of the continuous improvement process (Figure 1). The benefits of individual reflection and CEAB skill self-assessment were reported previously [11]. Self-assessment of skills at the start and end of a term allow students to reflect on their progress and to plan their own development. This approach and an on-line tool have been proposed as a prototype measurement tool for CEAB GA assessment development as students progress through their undergraduate programs (Figure 2) [11].

Our introductory and capstone chemical engineering design courses use of Comprehensive Assessment of Team-Member Effectiveness [16] (CATME) to provide mandatory, anonymous monthly feedback for individual students with respect to their team performance inculcates a culture of reflection and facilitates personal and professional skill development. Learning about learning and reflective strategies also introduces and teaches students about team, design, and innovation processes. A blended and active learning environment engages students, encourages reflection, and creates a sense making process where students use feedback to reflect. We also make use of collaborative learning and assessment methods [10] to encourage deep learning [1] and team development [12]. For example, team charters and project management techniques are used to encourage leadership and innovation development [9].

With assessment tools aligned with the learning objectives of the courses in place, a cooperative learning [13] situative framework [15] was developed to provide a 


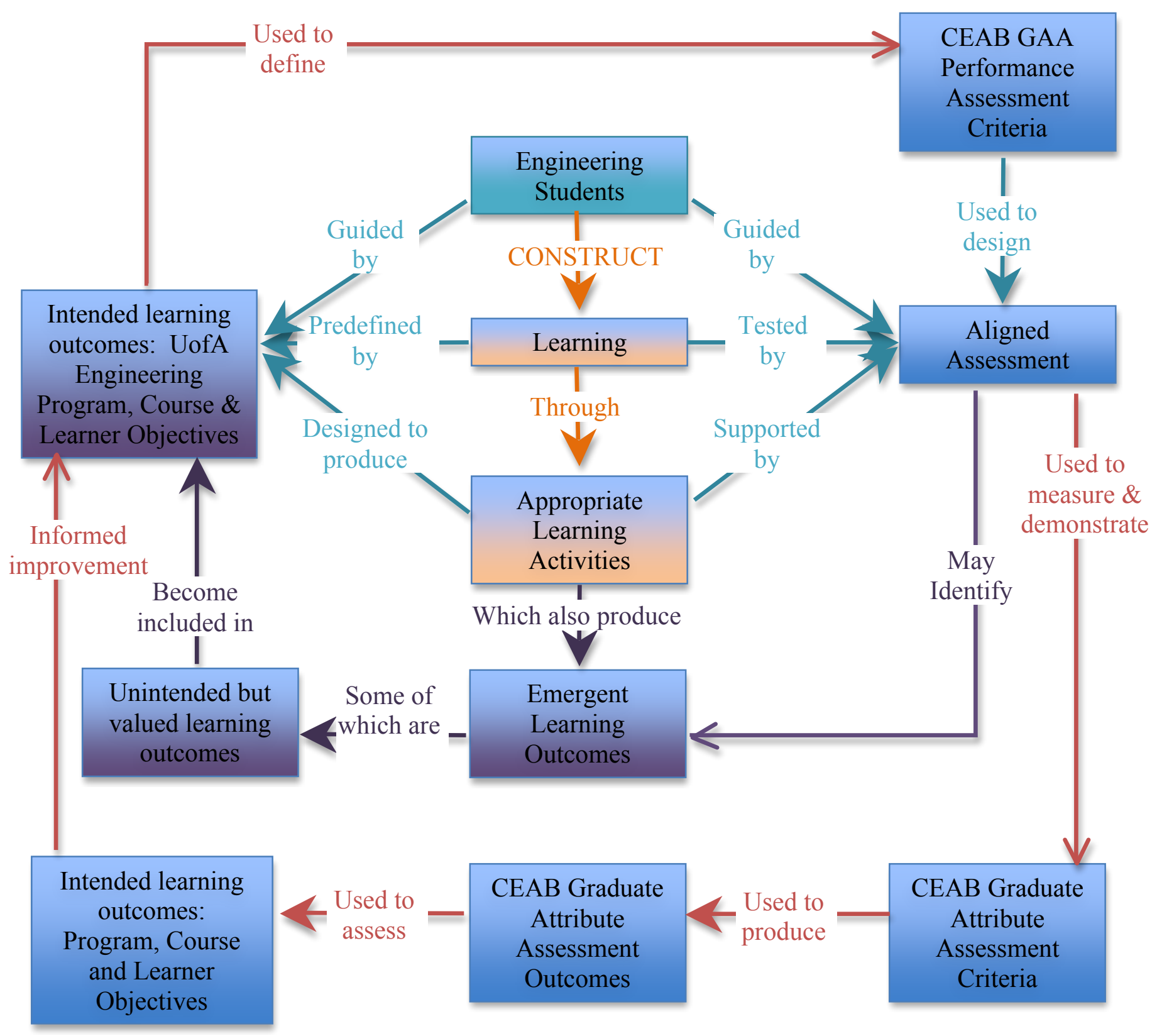

Figure 1. Continual improvement process algorithm for the University of Alberta Engineering Program Curriculum and Course Design Using CEAB GAA performance criteria based on a curriculum design process concept map (Hattie, 2009) illustrating constructive alignment (Biggs, 1996) as a core element and the feedback process of graduate performance measurement to inform program and course design (Jamieson 2015) -Adapted by MV Jamieson, 2015

framework where students may construct meaningful learning activities supporting leadership and teamwork development and that do not require the instructors to step in to micro-manage teams. In the capstone course, we initiated this development by blending course material delivery [9]. We monitor changes in CEAB attributes as illustrated in (Figure 2) in both courses.
This contribution explores the success and student acceptance of the assessment tools, the collaborative framework impacts, and the use of a pre introductory design course (optional bonus innovation) assignment as a method to encourage students to explore accessible literature on creativity, innovation, and leadership, and to contextualize their understanding into their design 


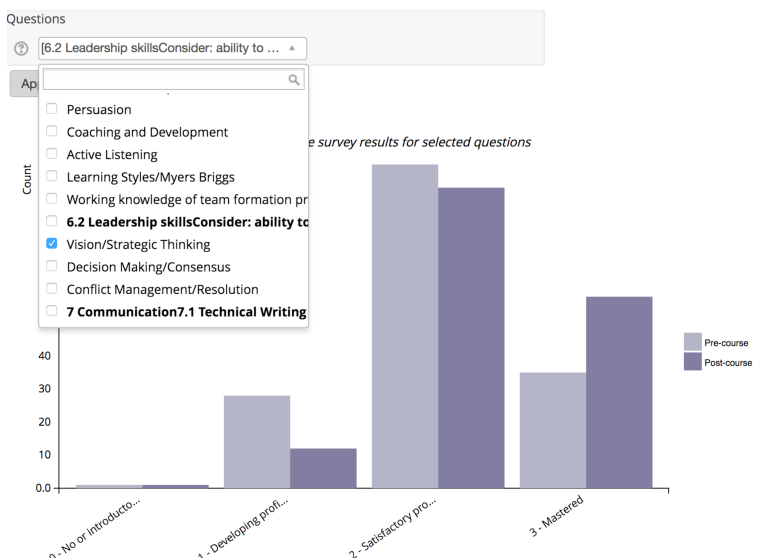

Figure 2. "Vision and Strategic Thinking" Pre - Post Course Results LMS Plot for the 2017 Capstone Cohort

learning experience. Key indicators of success include teaching evaluations, student engagement in the classroom and design lab, evidence of student discussion and debate as they make sense of materials and contextualize them, the online CEAB GA assessment prepost test data, and CAMTE factors.

\subsection{Literature Review}

Performance measurement as a method of continual instructional improvement is well supported [2-4,8]. Content and process are inextricably linked [17]. How student learning is assessed impacts learning, the construction of learning activities, and the probability of student attention to a learning activity. The environment where the learning activities are constructed also influences learning [15]. Instruction and evaluation best practices have developed over time to now include: cooperative work, writing, problem solving, real-world activities; rote learning and teaching have been deemphasized [9, 10, 15]. Linking assessment and instruction is a key principle for informing student progress and development [8]. Construction of learning activities where sense making and relevance are combined with an effectuation process [18,19] allow students to explore teamwork, leadership, and innovation and to anticipate further required action on their part. The effectuation process often requires practitioners to investigate means at hand and to apply them to create pathways to imagined ends or goals (Figure 3). Effectuation can lead to innovation and entrepreneurial actions [14,19]. An individual's environmental paradigm impacts their ability to innovate by influencing and shaping their knowledge community network interactions. Innovations are typically the result of the interaction of many individuals and ideas over the course of time. The idea that innovation is a discipline rooted in the conscious purposeful search for innovation opportunities [7] is consistent with the process of alternating convergent and

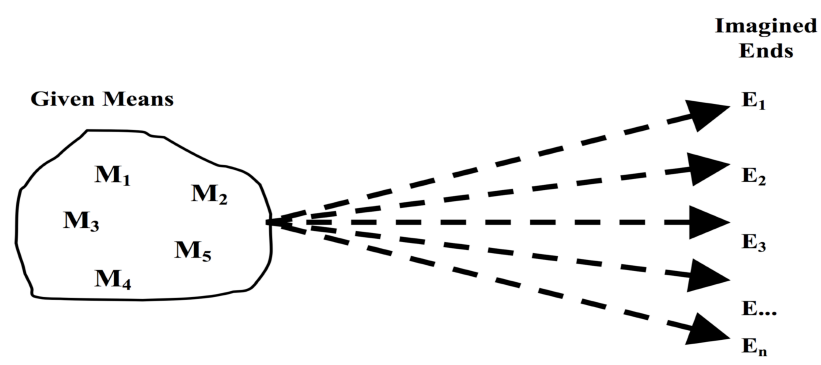

Figure 3 - Effectuation Model Use of Available Means to Achieve Imagined End Possibilities. [18]

divergent thinking required for both design and research. The motivation for the development of an innovation assignment for the introductory design course was to encourage student interaction with innovation, creativity, and leadership ideas related to design and teamwork.

\subsection{Problem Definition}

The intensity of teamwork in design courses can be a challenging experience for students. When a team is dysfunctional, student performance is impacted. In the past, we have observed students over and under contributing for a variety of reasons. Observed team issues typically revolve around a lack of contribution from and/or disruption by one or more team members due to some combination of inadequate skills and abilities, communication difficulties, project management skills, lack of motivation, conflicting expectations and commitments. At some point in the project work, students who perceive they are forced to complete more than their share and will receive a lower mark for their efforts become overwhelmed or dissatisfied and bring the issue to the attention of instructors. Typically instructors, including the authors, use peer input and assessment to try to mediate team conflicts and to assess individual contributions to project and term work and related grades [16]. While fair assessment of contributions is required, it does not address the creation of a positive environment where students can develop skills and become more comfortable with leadership, diversity, project planning, work execution work quality, technical innovation and creativity required for design. Peer ratings can have proven predictive validity but are ambiguous due to bias, leniency, and inaccurate differentiation by poor performers [16]. For example, CATME has been used in the introductory design course for more than four years and in the capstone design course for two years. Typical CATME factors adjusted (without self) ratings for design teams tend to be between 0.95 and 1.05 . Factors below 0.95 may indicate contribution or other concerns related to a team member. Teams often manage such concerns. Factors below 0.7 normally indicate a contribution concern related to an observable problem in team function 


\begin{tabular}{|l|l|}
\hline Table 1. Formal Cooperative Learning Environment for the \\
Process Design Sequence - Post Course Redevelopment \\
\hline Criteria & Process Design Course Aspect \\
\hline Positive & - Projects require contributions form all \\
team members for completion - marking \\
completed on a team basis. \\
-Team and project management \\
instruction. \\
-Coaching available weekly \\
-Early vision development using a bonus \\
assignment to picture their team in a \\
leadership, innovation, and creativity \\
context. \\
-Role models - courses are team taught \\
by an interdependent teaching team.
\end{tabular}

that the team is unable to manage effectively. CATME has been an invaluable tool for assisting instructors to quantify contributions with a behaviorally anchored scale. One of our goals is to reduce the need to use CATME factors to adjust grades by increasing team skill.

\subsection{Solutions Considered}

Cooperative learning requires [13]: face-to-face interaction, positive interdependence, appropriate use of interpersonal skills, individual accountability, and regular self-assessment of group functioning. When we assessed our capstone course against these criteria in 2014 we found deficiencies and addressed them during a blended learning course redesign [9]. We also modified the introductory course to include active learning elements and a team self-selection process. Table 1 summarizes the solutions implemented to construct meaningful team, leadership, and innovation learning activities in the design courses. Team self-assessment based on a rubric with individual CATME results as an input are the basis for a capstone team reflection assignment intended to foster cooperative learning. This assignment is completed monthly as part of a mandatory milestone review process. Grading for the reflections and milestone reviews is formative (complete, late, or incomplete).

Individual self-assessments have been performed in both design courses prior to team selection for many years and are currently supported by a Learning Management System (LMS) process where students build teams, identify team strengths and weaknesses, and plan to address them ahead of the first class. This process typically results in teams with better identified learning needs and who are better equipped to address challenges. Individuals are asked to focus on one or two topics for skill or knowledge development. These activities addressed organizational and learning needs but did not address team contribution concerns. The idea of a bonus innovation assignment that exposes students to innovation, creativity, and leadership ideas and processes at the beginning of the introductory design course was conceived. The assignment allows students to visualize their team using ideas described in readings and to describe how they would apply the concepts to their introductory design team, and more broadly to teams they join in the future.

\subsection{Significance}

The bonus assignment introduces students to innovation, creativity, and leadership and how to use these ideas in conjunction with the design process. It is intended and structured to take as much time and effort as students are willing to invest in learning about these ideas and their applications in their work. It is a low stakes, low risk activity with an upside for final grades and life long learning. It is also a low risk way to introduce concepts to students in an already heavy course.

\section{COLLABORATIVE FRAMEWORK}

In the introductory design course, the collaborative framework results from the integration of cooperative learning [13] and the situative context [15]. The structure of the course supports positive interdependence, individual accountability, face-to-face interaction, 
appropriate use of interpersonal skills, and regular assessment of group functioning [13] and engaged participation [15]. The framework includes a team midterm [10] and think, pair, share active learning activities within teams during class time. Teams of students were asked to sit with each other during class so that they could get to know each other and help each other learn as a team. The activities comprising the collaborative framework are summarized in Table 1.

The open-ended bonus assignment was introduced in the pre-course work section of the LMS. The rational for the assignment was connected to the course objectives and overview during the first class meeting. Students were given a variety of means and some possible ends with a request to consider how the ideas (means) could be used to benefit their team during the term (imagined ends). All outcomes were acceptable as it was not a mandatory assignment and could only improve their overall mark. Students were encouraged to read the assignment, do some research, and then decide if they had time or wanted to complete the written portion. The University of Alberta Vision was shared with the students during the first design class (emphasis added):

"To inspire the human spirit through outstanding achievements in learning, discovery, and citizenship in a creative community, building one of the world's great universities for the public good".

If submitted, the written portion of the assignment was graded on a team basis using the scale and rubric shown in (Table 2). A $3 / 5$ led to a $0.5 \%$ bonus and $5 / 5$ led to a $1 \%$ bonus on the final mark for all team members.

\subsection{Bonus Assignment Structure}

The bonus assignment is structured to be easily accessible using electronic devices and is integrated with the team selection pre course work. An introduction, a reading list (Table 3), and the collaborative framework are provided. Students are asked to read Originals: How
Non-conformists Move the World by Adam Grant (ebook suggested) or to watch his TED talk (html linked to the pre course material). An html link for the Ryerson University video "Engineers Want In" provides context for engineering and design in society. Student teams have one month to complete the assignment. The material and the description of the activities are provided online. How much research, reading, or written work students complete is up to them. The instructors do not follow up. The introduction includes statements intended to encourage participation:

"We will also be learning about teams, project management, and communication through experiential learning activities. ... Teams are selected for the entire term and $50 \%$ of the course grade is related to team based course work."

\subsection{Bonus Assignment Text For Students}

Purpose: This is an optional assignment meant to challenge your non-technical team skills. It is meant to give teams the opportunity to explore innovation and how it applies to engineering design teams. It will also give teams who choose to do this assignment an opportunity to get early feedback on their writing skills and to practice writing as a team. This is not a mandatory assignment.

Background: Innovation is an idea that creates value for someone. Innovation is defined as the act or process of introducing new ideas, devices, or methods. Creativity is the act of integrating ideas into something new. It is seeing something that others have not yet seen or turning an idea into reality. Generating solutions to an engineering problem is a creative act. Conceptual Engineering is a creative and innovative process within the boundary constraints of the problem. Sometimes, new ideas or new combinations of ideas or new materials or methods can shift the constraints or the efficiency resulting in breakthrough innovations. Unsurprisingly, this occurs almost always in collaborative team efforts.

Assignment: Choose one or more of the books from the reading list as a source. If you have another book you

\section{Table 2. Bonus Assignment Marking Rubric}

\begin{tabular}{|c|c|c|c|c|}
\hline \multirow[b]{2}{*}{ Grade } & \multicolumn{4}{|c|}{ Criteria } \\
\hline & Document & Hypothesis & Ideas & Plan to apply ideas \\
\hline 1 & Too brief or too long & Not stated & $\begin{array}{l}\text { Ideas were not sufficiently } \\
\text { developed }\end{array}$ & $\begin{array}{l}\text { Was not plausible or non } \\
\text { existent }\end{array}$ \\
\hline 2 & $\begin{array}{l}\text { Significantly exceeded the } \\
\text { maximum length or was not of } \\
\text { sufficient length to develop ideas. }\end{array}$ & Weakly stated & $\begin{array}{l}\text { Ideas were minimally } \\
\text { developed }\end{array}$ & Was weak \\
\hline 3 & Within the expected boundaries. & Clearly stated & Ideas were developed & Was meaningful \\
\hline 4 & Within the expected boundaries. & Concise & Ideas were well developed & $\begin{array}{l}\text { Meaningful and included } \\
\text { reflection }\end{array}$ \\
\hline 5 & Within the expected boundaries. & $\begin{array}{l}\text { Concise and } \\
\text { Insightful }\end{array}$ & $\begin{array}{l}\text { Ideas were well developed } \\
\text { and innovative }\end{array}$ & $\begin{array}{l}\text { Was meaningful included } \\
\text { reflection and testing strategies }\end{array}$ \\
\hline
\end{tabular}


would like to use in addition to one of the reference sources, just include it in your references. Determine how you can apply one of the concepts described in the readings to your teamwork and how it might impact your team. State it as a hypothesis. Describe your plan to use this idea in your course work. Is there a way to test your hypothesis? Summarize your hypothesis, ideas, and plan in 500-750 words.

\subsection{Marking Rubric and Assignment Direction}

Advice on how to complete the assignment, paraphrased below, and the grading rubric (Table 2) are provided. Students are advised to look for summaries of the books or to read the books if they have time to do so. The advice on how to do the assignment is meant to engage students in an internet search, and to exploit their curiosity and create team discussion regardless of whether the team completes the written portion of the assignment.

\subsubsection{How to do this assignment...}

The best way to do this assignment is to pick a subject area that means something to you personally. After watching the TED talk, "Engineers Want In", and getting an idea of what the readings are about pick a subject you'd like to pursue. It doesn't need to be the same for all team members. As you read, make notes, use quotes, page

\begin{tabular}{|l|c|l|}
\hline \multicolumn{3}{|c|}{$\begin{array}{c}\text { Table 3. List of Recommended Reading on Innovation and } \\
\text { Leadership for the Bonus Assignment }\end{array}$} \\
\hline Author(s) & Year & Title \\
\hline $\begin{array}{l}\text { Catmull, E., } \\
\text { Wallace, A. }\end{array}$ & 2014 & $\begin{array}{l}\text { Creativity, Inc.: Overcoming the } \\
\text { Unseen Forces That Stand in the } \\
\text { Way of True Inspiration. }\end{array}$ \\
\hline Colcleugh, D. & 2013 & $\begin{array}{l}\text { Everyone A Leader: A Guide to } \\
\text { High Performance Organizations } \\
\text { for Engineers and Scientists. }\end{array}$ \\
\hline Isaacson, W & 2014 & $\begin{array}{l}\text { The Innovators: How a Group of } \\
\text { Hackers, Geniuses, and Geeks } \\
\text { Created the Digital Revolution. }\end{array}$ \\
\hline Grant, A. & 2016 & $\begin{array}{l}\text { Originals: How Non-Conformists } \\
\text { Move the World. }\end{array}$ \\
\hline Johnson, S. & 2014 & How We Got to Now. \\
\hline Johnson, S. & 2011 & $\begin{array}{l}\text { Where Good Ideas Come From: } \\
\text { The Natural History of Innovation. }\end{array}$ \\
\hline Wilkinson, A & 2015 & The Creator's Code. \\
\hline
\end{tabular}

numbers, and include your thoughts, reactions and experiences. This reflection and preparation is a key step. Meet with your team and discuss what each of you has learned. Integrate what has been learned looking for common themes. Evaluate what you have produced. Reflect and plan the next steps. Do you have enough for a hypothesis about how innovation, leadership, or communication will apply to your teamwork? What needs to be done next? Can the work so far be integrated into a document (Use word with track changes or Google docs with editing suggestions to write together.) Narrow your focus. Describe how you plan to use one idea. Edit, and then edit again. This document should have edits from all team members. This process produces the best results for team reports. The workflow is key: individual preparation; then team discussion, integration, evaluation; and finally reflection and planning the next steps. You will need to use this process or one like it to produce the team assignments and the design project later in the term.

\section{COHORT DESCRIPTIONS}

The cohorts for this analysis comprise chemical engineering process design classes. The introductory design course (academic term 7) is offered to regular program students during the fall term and to co-op students during the winter term. The capstone design course (academic term 8) is offered during the winter term to a mix of co-op and regular program students.

\subsection{Cohort Blended Learning and Metacognitive Activity Description}

The introductory design course cohorts are labelled A, $\mathrm{B}, \mathrm{C}, \mathrm{D}$, and $\mathrm{E}$. The corresponding capstone design cohorts comprise cohorts $\mathrm{A}+\mathrm{B}$ and cohorts $\mathrm{C}+\mathrm{D}$. A baseline capstone cohort from before the implementation of either the bonus assignment or the release of CATME results to teams is labelled cohort $\mathrm{X}$. Cohort $\mathrm{X}$ was the first blended learning cohort for the capstone design course and did not complete CATME during the capstone design course but they did during the introductory design course. Cohort $\mathrm{X}(\mathrm{N}=127)$ did complete team evaluations during the capstone design course. They ranked one another for the scope contribution and quality their contributions and reflected on team behaviour based on a different rubric. Capstone design course cohorts $\mathrm{A}+\mathrm{B}$ $(\mathrm{N}=150)$ and $\mathrm{C}+\mathrm{D}(\mathrm{N}=162)$ completed monthly CATME evaluations with released feedback in conjunction with metacognitive individual and team-based activities (reflections). Introductory design course cohorts B, C, D, and E completed monthly CATME evaluations with released feedback but monthly reflections were not required. The cohort learning activities and developing collaborative structure are summarized in Table 4.

\subsection{Cohort Team Formation and Evaluation}

Team selection for both design courses is currently based on students assessing skills and demonstrating their team has the necessary skills to complete their design project work. Their goal is to assemble a balanced team. The selfselected teams are accountable for ensuring they have the skills required, to establish an agreed upon team structure, team values, performance and work quality norms. A plan to address gaps is required prior to team selection approval by the instructors. An electronic student skill assessment form linked team selection to CEAB GAA explicitly two years ago [11] as part of the chemical 
engineering capstone blended learning project [9]. It is currently used to gather pre and post course data for the capstone and the introductory chemical engineering design courses. Introductory design team selection was previously completed by instructors based on student input regarding self-reported classifications. Instructors took care to create diverse teams. Cohort A teams $(\mathrm{T}=12)$ were selected by instructors. Teams for cohorts $\mathrm{B}(\mathrm{T}=22)$, $\mathrm{C}(\mathrm{T}=20), \mathrm{D}(\mathrm{T}=26)$, and $\mathrm{E}(\mathrm{T}=19)$ were self selected based on CEAB GA skill assessment as noted in Table 4.

\section{RESULTS AND DISCUSSION}

CEAB GA skill self-assessment data were used on their own initially for course effectiveness evaluation. The post course self-assessments were completed prior to students receiving their final grade for the course [11]. After assessing data collected for cohort X, changes were initiated in the capstone and introductory design courses to improve criteria related to team selection, teamwork and leadership. CEAB GA attainment data and CATME factors (without self) have been used to evaluate the effectiveness of the course changes during subsequent iterations of both courses.

Positive self-assessed CEAB GA attainment shifts in 9 out of 10 skill attributes surveyed are observed for

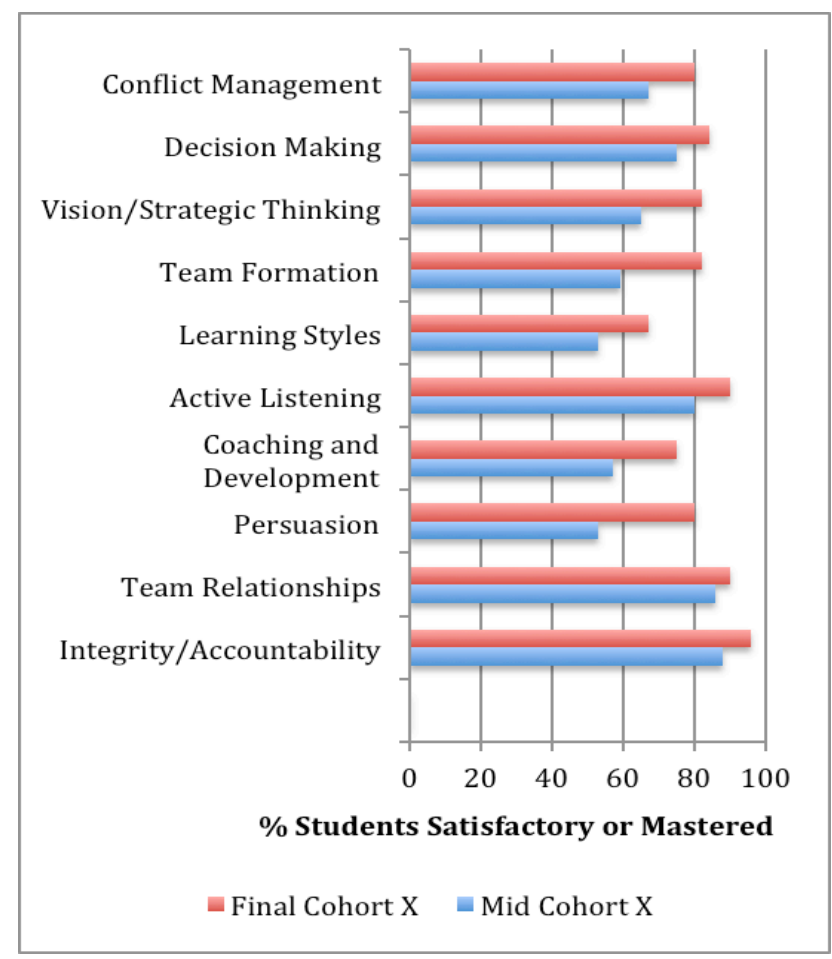

Figure 4. Team and Leadership Student Skill Self Assessment Results for Cohort X (25 Teams).

\begin{tabular}{|c|c|c|}
\hline & $\begin{array}{c}\text { Introductory Design Team } \\
\text { Activities }\end{array}$ & $\begin{array}{c}\text { Capstone Design Team } \\
\text { Activities }\end{array}$ \\
\hline $\bar{A}$ & $\begin{array}{l}\checkmark \text { Teams chosen by instructors } \\
\text { based on student input } \\
\checkmark \text { CATME evaluation twice } \\
\text { (early and final) } \\
\checkmark \text { Number of students: } \mathrm{N}=72 \text {, } \\
\text { Number of Teams: } \mathrm{T}=12\end{array}$ & \multirow{2}{*}{$\begin{array}{l}\checkmark \text { Teams self selected } \\
\text { based on CEAB GA } \\
\checkmark \text { Team charter } \\
\checkmark \text { Leadership roles } \\
\checkmark \text { Project Management } \\
\checkmark \text { CAMTE monthly } \\
\text { evaluation and } \\
\text { feedback released } \\
\checkmark \text { Team reflection and } \\
\text { discussion required } \\
\checkmark \text { Blended learning } \\
\checkmark \text { Combined A+B } \\
\checkmark \text { N=150, T=26 }\end{array}$} \\
\hline B & $\begin{array}{l}\checkmark \text { Teams self selected based on } \\
\text { CEAB GA } \\
\checkmark \text { CATME monthly evaluation } \\
\text { and feedback released } \\
\checkmark \text { Revised active learning } \\
\text { course structure } \\
\checkmark \mathrm{N}=89, \mathrm{~T}=22\end{array}$ & \\
\hline $\mathbf{C}$ & $\begin{array}{l}\checkmark \text { As per cohort B } \\
\checkmark \mathrm{N}=78, \mathrm{~T}=20\end{array}$ & \multirow{2}{*}{$\begin{array}{l}\checkmark \text { As per cohort A+B } \\
\checkmark \text { Combined C+D } \\
\checkmark \mathrm{N}=162, \mathrm{~T}=28\end{array}$} \\
\hline$\overline{\mathbf{D}}$ & $\begin{array}{l}\text { CATME monthly evaluation } \\
\text { and feedback released } \\
\checkmark \text { Revised active learning } \\
\text { course structure } \\
\checkmark \text { Bonus Assignment } \\
\checkmark \mathrm{N}=100, \mathrm{~T}=26\end{array}$ & \\
\hline $\mathbf{E}$ & $\begin{array}{l}\checkmark \text { As per cohort D } \\
\checkmark \mathrm{N}=74, \mathrm{~T}=19\end{array}$ & $\checkmark$ As per cohort $A+B$ \\
\hline $\bar{X}$ & \multicolumn{2}{|c|}{$\begin{array}{l}\text { Introductory as per cohort A, capstone monthly } \\
\text { evaluation quality / quantity matrix, blended learning } \\
\checkmark \text { Capstone course } \mathrm{N}=127, \mathrm{~T}=25\end{array}$} \\
\hline
\end{tabular}

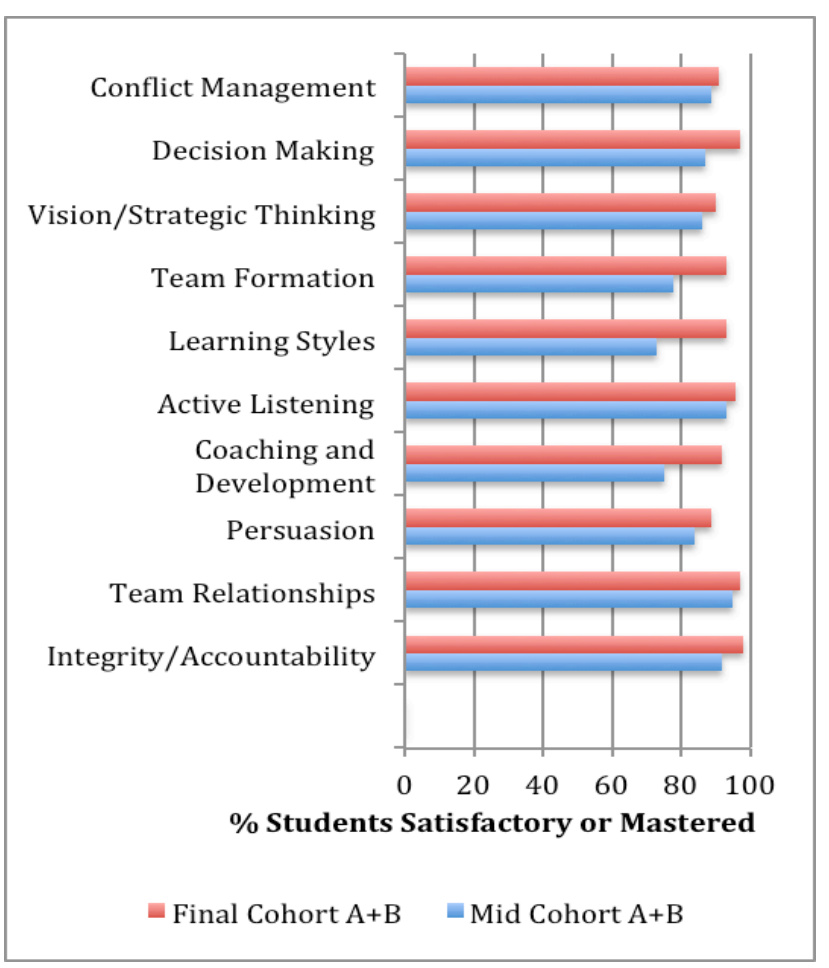

Figure 5. Team and Leadership Student Skill Self Assessment Results for Cohort A+B (26 Teams). 
capstone cohorts (A-E) relative to the attainment of the baseline cohort $\mathrm{X}$ and capstone design cohorts $(\mathrm{A}+\mathrm{B})$ and $(\mathrm{C}+\mathrm{D})$ both experienced similar shifts with the largest shifts occurring in leadership skills. These outcomes are illustrated in Figures 4-6 for CEAB GAA 6 (the ability to work as a member and leader of a team). Outcomes for cohort $\mathrm{X}$ are shown in Figure 4. Results for cohort $(\mathrm{A}+\mathrm{B})$ (Figure 5) and cohort (C+D) (Figure 6) are similar to each other and indicate a greater positive shift than observed for cohort X.

The frequency of low CATME factors for all cohorts in the introductory design course (Figure 7) show an improvement in CATME factors (without self) for Cohorts D and E. For these two cohorts, the optional bonus assignment was included in the curriculum, and integrated in class discussions. The written portion was completed by $30 \%$ of cohort $\mathrm{D}$ and $50 \%$ of cohort $\mathrm{E}$. There is also a marked reduction in the percentage of students in the introductory design course with team problems they could not resolve on their own. This effect appeared to carryover to the capstone course (Figure 8.)

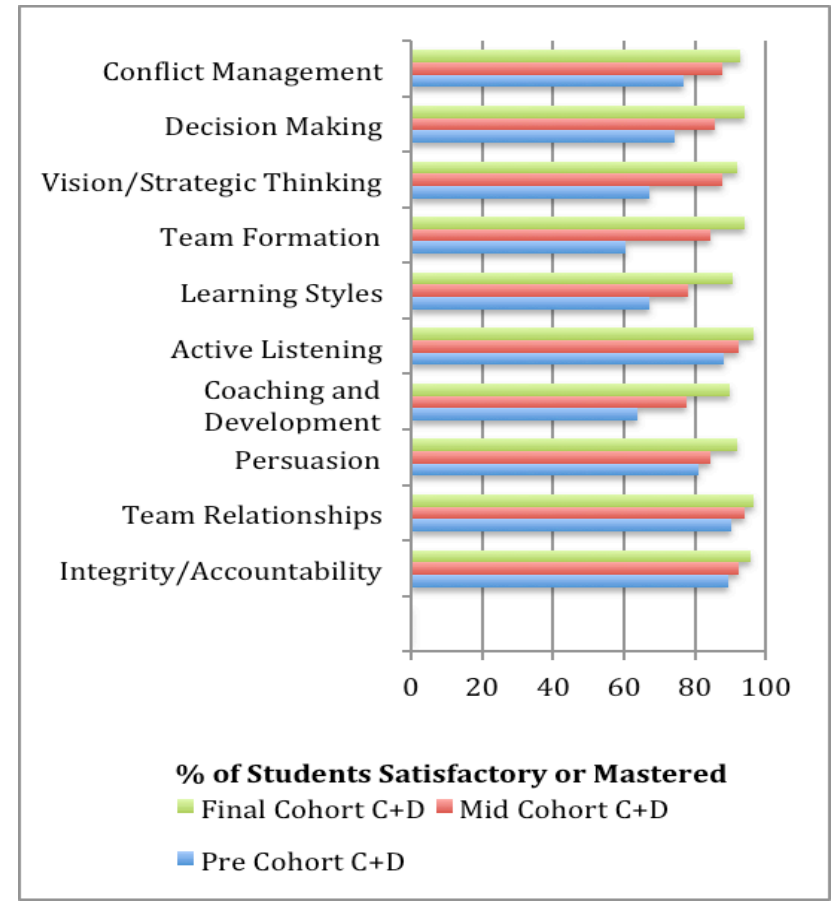

Figure 6. Team and Leadership Student Skill Self Assessment Results for Cohort C+D (28 Teams).

\section{CONCLUSIONS}

The introduction of an optional assignment on team and leadership skills in the introductory design course did not improve CEAB GA attainment during the course based on self-assessed student perception data, beyond other course changes designed to support collaborative learning and continuous improvement. However, the bonus innovation assignment did impact CATME factors in the introductory design course and subsequently in the capstone course. The percentage of students with reported contribution deficits dropped by half or more. The percentage of students with problem performance that was not resolved by the teams dropped by two thirds. These outcomes demonstrate the short and long term benefits of the optional leadership and innovation assignment irrespective of completion status.

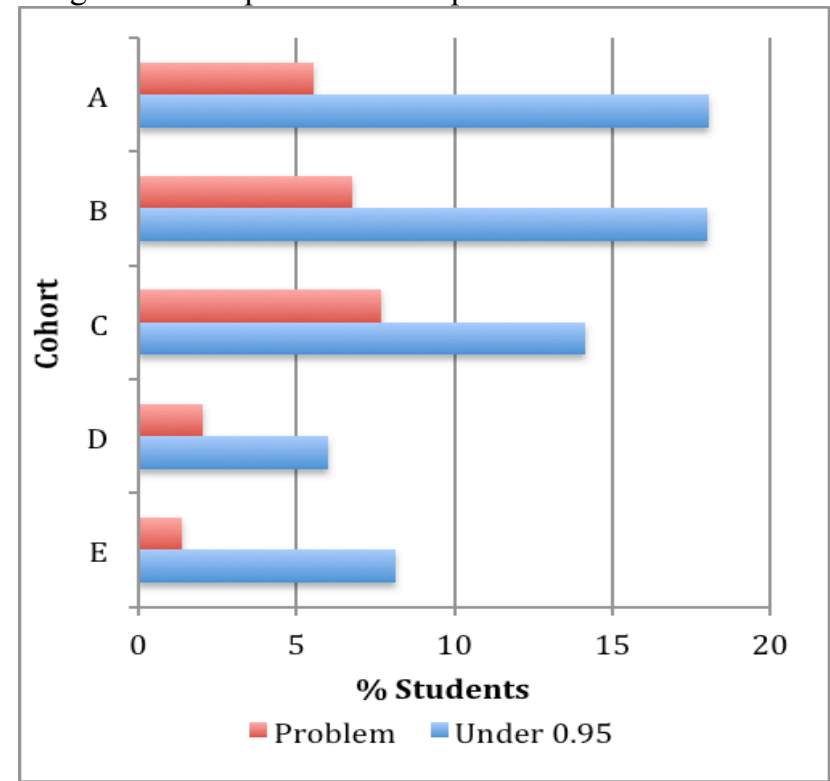

Figure 7. Percent of Students in Introductory Design Cohorts with a low CATME Factor (adjusted without self)

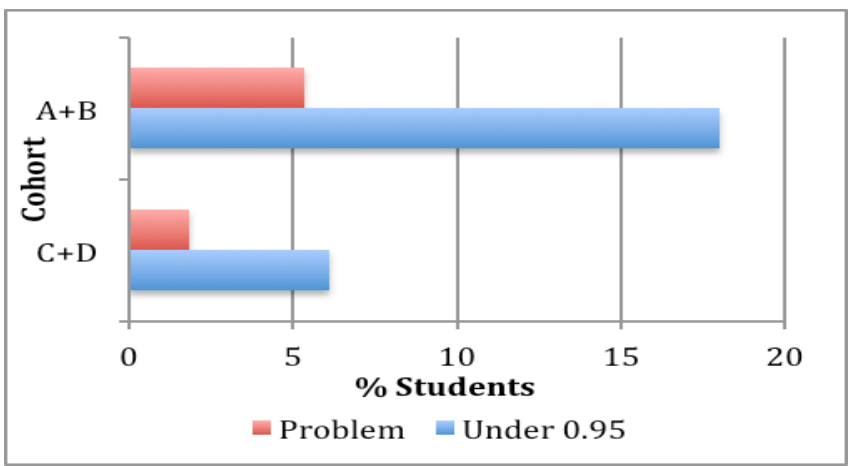

Figure 8. Percent of Students in Capstone Design Cohorts with a low CATME Factor (adjusted without self)

\section{Acknowledgements}

The design course redevelopment was funded by the Provost's Office (University of Alberta). The CTL blended learning research project, of which this research is a part, received research ethics approval from the University of Alberta Research Ethics Board, No. Pro00048272. The authors acknowledge with thanks the support given by Dr. Norma Nocente, Craig Jamieson, and the CTL production staff, and the graduates of our Chemical Engineering Design Classes. 


\section{References}

[1] Ken Bain, What the Best College Teachers Do. Cambridge, Mass.: Harvard University Press 2004. \{ISBN: 9780674013254\}

[2] J.B. Biggs, What the Student Does: teaching for enhanced learning. Higher Education Research and Development, vol. 18 , no. 1,1999 , pp. 57-75.

[3] J.B. Biggs, Teaching for Quality Learning at University: What the Student Does. Buckingham; Philadelphia, PA: Society for Research into Higher Education: Open University Press, 2003.

[4] J.B. Biggs, C.S. Tang, \& Society for Research into Higher Education, Teaching for quality learning at university: What the Student Does, (Maidenhead, McGraw-Hill Education. 2011), 389pp. \{ISBN: 978-0335-22126-4\}.

[5] Canadian Engineering Accreditation Board, "Canadian Engineering Accreditation Board: Accreditation Criteria and Procedures", Ottawa: Canadian Council of Professional Engineers, 2014. Accessed June 20, 2015.

[6] E.L. Cussler, "Future of the Lecture". AIChE Journal DOI 10.1002/aic.14807, 2005

[7] Peter Drucker,"The Discipline of Innovation," Harvard Business Review, 1985.

[8] J. Hattie, "The Black Box of Tertiary Assessment: An Impending Revolution", in L. H. Meyer, S. Davidson, H. Anderson, R. Fletcher, P.M. Johnston, \& M. Rees (Eds.), Tertiary Assessment \& Higher Education Student Outcomes: Policy, Practice \& Research, pp. 259-275, Wellington, New Zealand: Ako Aotearoa, 2009.

[8] J.L. Herman, A Practical Guide to Alternative Assessment. Alexandria, VA: Association for Supervision and Curriculum Development, 1992. \{ISBN: 0-87120-197-6\}

[9] Marnie V. Jamieson, "Application of Blended and Active Learning to Chemical Engineering Design Instruction", M.Sc. Thesis, University of Alberta, 2016

[10] Marnie V. Jamieson and John M. Shaw, "Team Midterm in an Introductory Process Design Course," in Proc. 2016 Canadian Engineering Education Conf. (CEEA16) Paper 036 Dalhousie University; 19-22 June 2016.
[11] Marnie V. Jamieson and John M. Shaw, "Pre and Post Course students self assessment of CEAB Graduate Attributes - A Tool for Outcomes Assessment, Student Skill and Course Improvement," in Proc. 2016 Canadian Engineering Education Conf. (CEEA16) Paper 038 Dalhousie University; 19-22 June 2016.

[12] Marnie V. Jamieson, Leah Goettler, Albert Liu, and John M. Shaw, "To Teach is to Learn: Student and Instructor Perspectives on Assignment Development as a Springboard to Deep Learning," in Proceedings of the 13th International CDIO Conference, Calgary, Canada, 18-22, June, 2017

[13] D.W. Johnson, R.T. Johnson \& K.A. Smith (1998) Active Learning: Cooperation in the College Classroom $\left(2^{\text {nd }}\right.$ ed) 1998. Edina, MN: Interaction Book Company.

[14] S. Johnson, Where Good Ideas Come From: The Natural History of Innovation, Riverhead Trade, 2011. Chapter 1: "Reef, City, Web: Darwin's paradox"

[15] A. Johri \& B.M. Olds, "Situated engineering learning: Bridging engineering education research and the learning sciences," Journal of Engineering Education, 100(1), 151-5 (2011).

[16] M.W. Ohland, M.L. Loughry, D.J. Woehr, C.J. Finelli, L.G. Bullard, R.M. Felder, R.A. Layton, H.R. Pomeranz, \& D.G. Schmucker, "The Comprehensive Assessment of Team Member Effectiveness: Development of a Behaviorally Anchored Rating Scale for Self and Peer Evaluation," Academy of Management Learning \& Education, vol. 11 no. 4, pp. 609-630, 2012,.

[17] L. Resnick, \& L. Klopfer, (Eds.) Toward the Thinking Curriculum: Current Cognitive Research, 1989. Alexandria, VA: Association for Supervision and Curriculum Development.

[18] S. Sarasvathy, \& S. Venkataraman, "What Makes Entrepreneurs Entrepreneurial?," 2001. http://www.effectuation.org/paper/what-makesentrepreneurs-entrepreneurial

[19] S. Sarasvathy, \& S. Venkataraman, "Entrepreneurship as Method: Open Questions for an Entrepreneurial Future," Entrepreneurship Theory and Practice. 35, No. 1: p. 113-135. 